\title{
PENGEMBANGAN BUSANA PESTA MALAM DENGAN SUMBER IDE BUSANA RATU ELIZABETH KERAJAAN INGGRIS
}

\author{
Ni Luh Desi Ariati, Dr. I Gede Sudirtha, S.Pd,M.Pd., Made Diah Angendari, \\ S.Pd,M.Pd. \\ Jurusan Pendidikan Kesejahteraan Keluarga \\ Universitas Pendidikan Ganesha \\ Singaraja, Indonesia \\ e-mail; desiariyanti234@gmail.com, gede.sudirtha@undiksha.ac.id, \\ diah.angendari@undiksha.ac.id
}

\begin{abstract}
ABSTRAK
Tujuan dari penelitian ini adalah untuk (1) mendefinisikan proses pengembangan busana pesta malam; (2)menerangkan hasil pengembangan produk pengembangan busana pesta malam dengan sumber ide busana Ratu Elizabeth Kerajaan Inggris. Jenis penelitian yang digunakan adalah Penelitian dan Pengembangan (Research and Development) dengan model pengembangan ADDIE. Model ADDIE terdiri dari 5 langkah yaitu; analyze (analisis), design (desain), development (pengembangan), implementation (implementasi), evaluation (evaluasi). Subyek dari penelitian ini adalah 2 orang ahli isi dan 2 orang ahli produk. Validasi dari ahli isi akan digunakan untuk menguji produk dengan menggunakan lembar kuisioner yang sudah valid. Hasil pengembangan menunjukkan bahwa, (1) penelitian ini menggunakan proses pengembangan model ADDIE. Adapun langkah-langkah penelitian ADDIE yaitu: (a) analisis, pada proses ini peneliti menganalisis sumber ide dalam pengembangan busana pesta malam; (b) tahap kedua yaitu perancangan, pada tahap ini peneliti membuat desain busana pesta yang akan dikembangkan sesuai dengan sumber ide yang digunakan yaitu busana pesta Ratu Elizabeth Kerajaan Inggris; (c) pengembangan, pada tahap pengembangan peneliti melakukan pengembangan terhadap desain yang telah dibuat menggunakan model pengembangan ADDIE; (d) tahap selanjutnya yaitu implementasi, pada tahap ini dilakukan uji produk terhadap hasil pengembangan busan pesta malam; (e) tahap yang terakhir yaitu evaluasi, pda tahp ii dilakukan evaluasi dari keseluruha proses pengembangan. Evaluasi didapat dari hasil uji produk oleh ahli busana. (2) penelitian ini menghasilkan sebuah produk berupa busana pesta malam dengan sumber ide busana Ratu Elizabeth Kerajaan Inggris. Berdasarkan uji produk ahli busana menunjukkan bahwa bahwa pengembanga busana pesta malam dengan sumber ide busana Ratu Elizabeth Kerajaan Inggris memiliki tingkat pencapaian sangat baik dengan presentase $90,52 \%$.
\end{abstract}

Kata kunci: Busana Pesta Malam, Pengembangan, Sumber Ide.

\section{ABSTRACT}

This research aimed at (1) defining the process of development of nightgown with the source of idea based on Queen Elizabeth fashion in English Kingdom; (2) explaining the result of the development of nightgown with the source of idea based on Queen Elizabeth 
fashion in English Kingdom. The design of this study was Research and Development with ADDIE model. ADDIE model consisted of 5 steps, they are; analyze, design, development, implementation, and evaluation. The subjects of this study were 2 content expertizes and 2 product expertizes. Validation from content expertize was used to test the product by using the valid questionnaire. The result of development showed that, (1) this study used the development process of ADDIE model. As for the steps of ADDIE model are: (a) analyze, in this process the researcher analyzed the source of idea of the development of nightgown; (b) the second step is design, in this process the researcher made the design of nightgown which was developed based on the source of idea being used, it was nightgown of Queen Elizabeth fashion in English Kingdom; (c) development, in this step the researcher did a development to the design which had been made by using ADDIE model; (d) the next step was implementation, in this step, product test was done to the result of development of the nightgown: (e) the last step was evaluation, in this step the evaluation of the development process was done. Evaluation was found from the result of product test by the fashion expertize. (2) the result of this study was a product in form of a nightgown with the source of idea based on Queen Elizabeth fashion in English Kingdom. Based on the product test by fashion expertize, it showed that the development of nightgown with the source of idea based on Queen Elizabeth fashion in English Kingdom had a best level of achievement with percentage $90.52 \%$.

Keywords: nightgown, development, source of idea

Setiap negara atau wilayah
memiliki karakteristik berbeda sebagai
identitas yang diwujudkan dalam bentuk
pakaian adat atau khas, lagu-lagu daerah,
maupun bahasa. Hal tersebut dapat
dijadikan suatu ciri khas dari setiap
negara atau daerah secara umu bertujuan
agar mudah dikenal oleh masyarakat luas.
Salah satu identitas wilayah adalah
bentuk pakaian atau busana yang
digunakan. Busana merupakan
kebutuhan pokok yang harus dipenuhi
oleh setiap orang (Siskawati,2010:1). Pakaian sudah dikenal manusia sejak zaman purbakala dan selalu berkembang sesuai dengan zamannya terutama baju wanita yang memiliki banyak variasi model dan telah menjadi ciri khas suatu negara. Bangsa yang satu mengenal bangsa yang lainnya melalui pakaian tradisional mereka. Sampai sekarang ini pakaian tradisional masih digemari terutama pada acara-acara khusus. Terutama pakaian tradisional wanita sangat menarik dan memiliki nilai budaya yang tinggi. Terutama pakaian tradisional wanita sangat menarik dan memiliki nilai budaya yang tinggi. Seiring dengan perkembangan zaman, busana juga digunakan sebagai simbol status, jabatan, ataupun kedudukan seseorang yang memakainya (Bryka, 2012:1). Selain sebagai alat pelindung diri, busana juga berfungsi sebagia alat pelindung diri, busana juga berfungsi sebagai tempat penuang ide dan kreativitas seseorang untuk tetap mempertahankan budaya yang dimiliki dan sebagai identitas suatu daerah atau negara. Budaya yang berkembang begitu cepat, tidak membuat teori busana yang ada menjadi hilang dan berubah seluruhnya.

Perlunya mengetahui karakteristik kebudayaan daerah atau negara lain sangat penting dalam menambah wawasan dan tidak mengunggulkan egoisme untuk mengenal identitas daerah atau negara lain. Pada umumnya pakaian khas Inggris, Irlandia, Scotlandia dan Wales mempunyai suatu kesamaan untuk itu sebenarnya cukup sulit untuk membedakan pakaian khas dari beberapa negara tersebut. warna dan motif dari pakaian adalah setipe dan bentuknya juga identik. Baju ini sering kita lihat lewat sebuah cerita negeri dongeng yang sering digunakan oleh seorang putri, karena Inggris adalah negara kerajaan. Pakaian ini menyempit dibagian pinggang seperti korset dan melebar pada bagian bawah.

Saat ini negara Inggris dipimpin oleh seorang Ratu bernama Ratu Elizabeth. Bagi masyarakat Inggris, Ratu Elizabeth bukan hanya sebagai orang yang dihormati atau seorang kepala negara semata. Ratu Elizabeth juga 
dianggap memiliki peranan penting dalam hal gaya hidup rakyat Inggris terutama yang berhubungan dengan fashion. Pasalnya sang ratu yang telah menjadi kepala negara terhitung selama 63 tahun ini, diketahui memiliki selera fashion yang tinggi dan mampu mempengaruhi banyak wanita Inggris pada jamannya. Ratu Elizabeth terkenal dengan gaya busananya yang trendi dan selalu mengikuti perkembangan mode. la juga terkenal sangat teliti memilih busana yang akan dikenakan dan tampilkan di depan publik. Media menyebutkan bahwa busana Ratu Elizabeth adalah bentuk dari penghormatan, sebuah kekuatan dan sebagai petunjuk kekuasaan. Ratu Elizabeth tidak menjadi tren fashion dan lebih memilih gaya busananya sendiri. la juga terkenal sebagai seorang tokoh yang gemar berbusana terang. Sedari muda, Ratu Elizabeth gemar mengenakan tampilan busana yang berwarna cerah.

Hal ini ditunjukkan agar lebih mudah dikenali oleh publik. Selain itu, Ratu Elizabeth juga gemar mengenakan busana bernuansa glamour dengan sentuhan manik-manik, atau bebatuan berharga pada gaunnya. Salah satu gaun tersohor dari Ratu Elizabeth adalah gaun pengantin yang bersiluet lurus namun tetap memberikan kesan elegan dan sophisticated pada tahun 1940. Saat ini, menuju ulang tahunnya yang ke-90, Ratu Elizabeth berusaha untuk tampil berbusana sesuai usianya dengan anggun dan tetap mengusung nuansa cerah.

Busana yang sering digunakan

Ratu Elizabeth menggunakan warna cerah dengan model yang trendi. Selain itu detail dari busana yang beliau kenakan banyak terdapat hiasan berupa manikmanik dan bordiran. Karena itu karakteristik dari busana yang beliau kenakan lebih banyak menggunakan warna-warna cerah dengan hiasan manikmanik yang berwarna-warni. Pada masa muda, Ratu Elizabeth lebih suka mengenakan busana dengan bentuknya menyempit pada bagian atas dan melebar pada bagian bawah, dengan detail hiasan berupa sulaman, bordiran dan manikmanik dan aksesoris kepala berupa mahkota atau topi, seperti contoh busana yang telah dipaparkan. Saat ini Ratu Elizabeth lebih banyak menggunakan busana dengan model siluet lurus, hal ini dikarenakan umur Ratu Elizabeth tidak muda lagi, beliau memilih gaya berbusana disesuikan dengan umur beliau saat ini.

Busana tersebut menunjukkan bahwa, Ratu Elizabeth sangat gemar menggunakan busana dengan warnawarna cerah, meskipun umur beliau sudah tidak muda lagi.Dengan adanya hal tersebut penulis tertarik untuk mengembangkan sebuah busana yang mengambil sumber ide dari busana pesta Ratu Elizabeth. Busana yang akan penulis kembangkan adalah busana pesta malam dengan mengambil ide busana Ratu Elizabeth. Busana pesta malam dipilih karena busana pesta malam merupakan busana yang menggunakan warna-warna cerah dan berani yang memiliki kesan glamour yang sesuai dengan karakteristik busana dari Ratu Elizabeth. Teknik pengembangan yang akan digunakan yaitu teknik pengembangan model ADDIE, dimana pengembangan model ADDIE merupakan salah satu model pengembangan yang bertujuan untuk mengembangkan suatu produk baru, atau menyempurnakan produk yang telah ada dan dapat dipertanggungjawabkan hasilnya. Diharapkan dengan menggunakan model pengembangan ini, dapat dikembangkan sebuah produk berupa busana pesta malam dengan sumber ide busana Ratu Elizabeth Kerajaan Inggris tanpa meninggalkan ciri khas dari busana Ratu Elizabeth tersebut. Teknik jahit yang akan digunakan dalam proses pengembangan busana ini adalah teknik jahit adi busana, dimana teknik jahit tersebut memerlukan kreativitas yang tinggi dan tingkat kerapian, sehingga proses pembuatan busana memerlukan waktu yang lama. Hal ini mengingat bahwa jenis busana yang dikembangkan adalah busana pesta malam yang memiliki kesan mewah, anggun dan glamour.

Berdasarkan latar belakang yang telah dipaparkan tersebut, perlu adanya penelitian untuk masalah tersebut dengan mengambil judul: PENGEMBANGAN BUSANA PESTA MALAM DENGAN 


\section{SUMBER IDE BUSANA RATU METODE PENELITIAN}

Metode yang digunakan dalam penelitian ini adalah penelitian pengembangan. Pada penelitian pengembangan terdapat beberapa jenis model. Model yang digunakan adalah pengembangan model ADDIE. Model pengembangan ADDIE adalah salah satu model pengembangan yang bertujuan untuk mengembangkan suatu produk baru, atau menyempurnakan produk yang telah ada dan dapat dipertanggungjawabkan hasilnya

Model ADDIE terdiri dari lima langkah, yaitu analisis (analyze), perancangan (design), pengembangan (development), implementasi (implementation), dan evaluasi (evaluation). Model ADDIE memberikan peluang untuk melakukan evaluasi terhadap aktivitas pengembangan pada setiap tahap. Hal ini berdampak positif terhadap pengembangan kualitas produk pengembangan.Dampak positif yang ditimbulkan dengan adanya evaluasi pada setiap tahapan adalah meminimalisir

\section{ELIZABETH KERAJAAN INGGRIS.}

tingkat kesalahan atau kekurangan produk pada tahap akhir model ini.

Subyek uji coba dari penelitian ini merupakan 2 orang ahli busana. Uji coba dilakukan terhadap hasil produk pengembangan berupa busana pesta malam dengan sumber ide busana Ratu Elizabeth Kerajaan Inggris.

Dalam penelitian pengembangan ini menggunakan teknik analisis deskritif kuantitatif dan analisis deskritif kuatitatif. Teknik analisis ini digunakan untuk mengolah data yang diperoleh melalui angket dalam bentuk deskritif presentase. Rumus yang digunakan untuk menghitung presentase dari masing-masing subyek adalah sebagai berikut:

$$
N=\frac{\text { skorperolehan }}{\text { Skormaksimal }} \times 100 \%
$$

Untuk dapat memberikan makna dan pengambilan keputusan digunakan ketetapan sebagai berikut:
Tingkat Pencapaian

$90 \%-100 \%$

$75 \%-89 \%$

$65 \%-74 \%$

$55 \%-64 \%$

$0-54 \%$
Kualifikasi

Sangat Baik

Baik

Cukup

Kurang

Sangat kurang

(Sumber: Tegeh, dkk, 2014)

HASIL DAN PEMBAHASAN Hasil Penelitian

\section{Proses Pengembangan Busana Pesta Malam dengan Sumber Ide Busana Ratu Elizabeth Kerjaaan Inggris}

Berdasarkan langkah dalam penelitian pengembangan ADDIE, maka didapatkan hasil sebagai berikut:

\section{Analisis (analyze)}

Pada tahap pertama yang peneliti lakukan dalam pengembangan busana pesta ini adalah menganalisis dari sumber ide busana pesta yang dikembangkan. Sumber ide yang dijadikan acuan dalam pengembangan busana pesta ini adalah busana Ratu Elizabeth di Kerajaan Inggris. Dari sumber ide tersebut akan 
dikembangkan unsur-unsur, prinsipprinsip dan karakteristik dari busana Ratu Elizabeth yang kemudian akan dikembangkan menjadi sebuah produk berupa busana pesta malam dengan sumber ide dasar busana Ratu Elizabeth Kerajaan Inggris. Busana pesta Ratu Elizabeth merupakan salah satu sumber ide yang penulis gunakan dalam pengembangan busana pesta malam. Ciri khas dari busana yang beliau gunakan terlihat dari bentuk busananya yaitu menyempit pada bagian bawah dan melebar pada bagian atas. Dengan menggunakan hiasa manik-manik dan bordiran. Bentuk busana pada bagian atas terlihat terbuka untuk memperlihatkan sisi anggun dan elegan dari seorang wanita.

Busana yang sering digunakan Ratu Elizabeth memiliki warna-warna yang cerah. Seperti yang telah dipaparkan didalam latar belakang Ratu Elizabeth sangat gemar menggunakan busana dengan warna-warna yang cerah seperti warna merah, kuning, biru, orange, hijau dan ungu. Dari hal tersebut penulis akan mengembangkan busana pesta malam dengan menggunakan salah satu warna yang gemar digunakan oleh Ratu Elizabeth.

Selain gemar menggunakan busana yang cerah, Ratu Elizabeth juga gemar menggunakan aksesoris dan milineris. Aksesoris yang sering beliau gunakan berupa anting dan kalung. Sedangkan untuk milinerisnya beliau lebih gemar menggunakan topi dengan hiasan bunga-bunga dan pita pada bagian depan maupun bagian samping. Dari hal tersebut, penulis mengembangkan sebuah bentuk aksesoris kepala dengan mengambil bentuk seperti topi dengan pemilihn warna yang cerah dengan hiasan bunga-bunga.

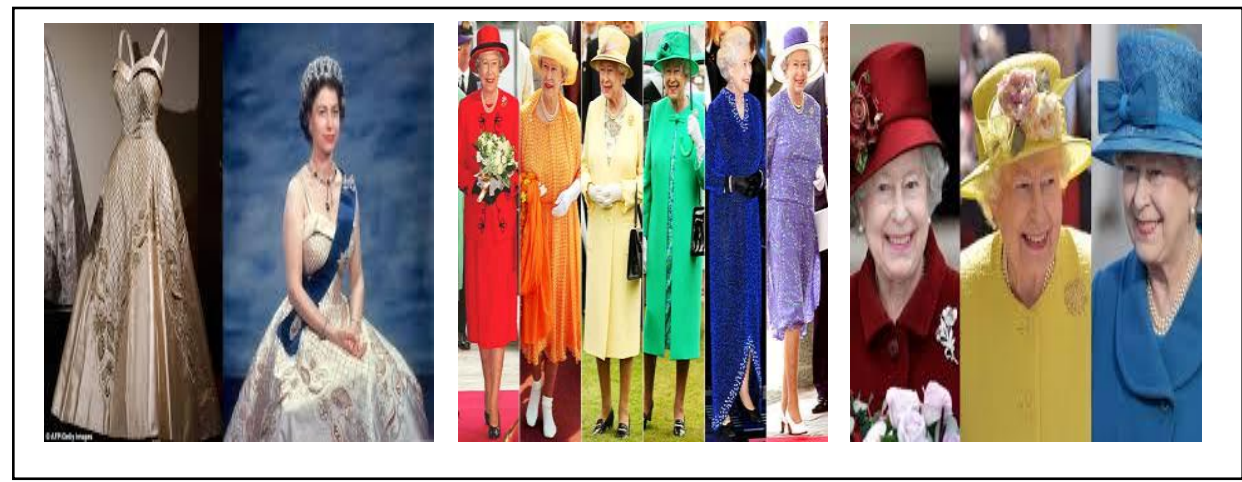

Gambar 1. Sumber Ide Pengembangan Busana Pesta Malam

\section{Desain (design)}

Pada tahap kedua ini yang peneliti lakukan adalah mendesain busana pesta malam yang akan dikembangkan. Setelah melakukan analysis, maka peneliti mendesain model busana pesta malam yang akan dikembangkan. Dalam desain tersebut dilengkapi dengan detail warna busana, detail bagian-bagian busana, motif bahan yang akan digunakan dan dilengkapi dengan aksesoris dan milineris yang melengkapi dari busana yang penulis kembangkan.

Dari analisis yang telah dipaparkan oleh penulis, busana pesta tersebut menggunakan bentuk yang sama dengan busana pesta Ratu Elizabeth. Dimana bentuk dari busana Ratu Elizabeth adalah menyempit pada bagian atas dan melebar pada bagian bawah.Pemilihan warna untuk busana pesta malam menggunakan warna perpaduan warna biru dan silver. Warna biru dipilih karena Ratu Elizabeth sangat gemar menggunakan warna-warna cerah salah satunya warna biru. Agar warna biru terlihat lebih mewah dan elagan, penulis memadukan dengan warna silver sebagai kombinasi untuk perpaduan warna. Bahan utama yang digunakan adalah kain satin berwarna silver yang dipadukan dengan kain brokat berwarna biru. Selain dipadukan dengan kain brokat berwarna biru, busana tersebut juga akan dipadukan dengan kain 
kaca berwarna silver. Untuk bahan pendukung pembuatan busana ini antara lain: kain hero berwarna silver, kain tulle kaku abu, dan kain tulle berwarna kulit. Untuk hiasan kepala penulis mengambil inspiarasi dari aksesoris dan milineris yang sering digunakan oleh Ratu
Elizabeth. Bahan yang dipergunakan untuk membuat aksesoris antara lain: tulle kaku, hiasan bunga-bunga, permata kecil dan bulu ayam. Untuk warna aksesoris senada dengan warna dari busana.

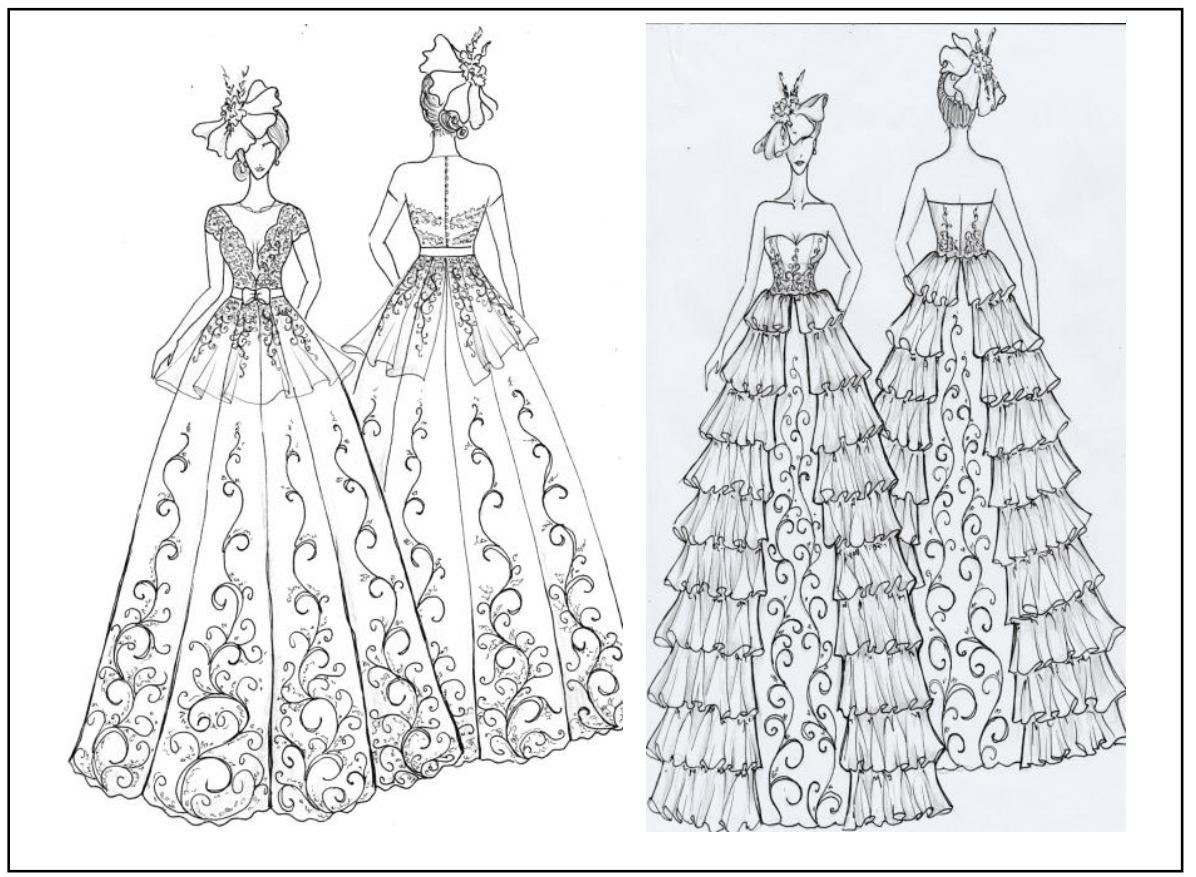

Gambar 2. Desain Busana Pesta Malam yang Dikembangkan

\section{Pengembangan (development)}

Tahap selanjutnya yaitu tahap pengembangan. Pada tahap ini peneliti meliputi proses daripada pembuatan busana pesta malam dengan sumber ide busana Ratu Elizabeth Kerajaan Inggris. Pada proses pengembangan ini meliputi tiga tahapan yaitu: persiapan, pelaksanaan dan evaluasi. Adapun tahapan-tahapan tersebut adalah:

\section{Tahap Persiapan}

Pada tahap ini peneliti menyiapkan gambar kerja, kemudian dilanjutkan dengan mengambil ukuran yang diperlukan untuk membuat busana pesta. Selanjutnya peneliti membuat pola yang akan digunakan untuk membuat busana pesta. Setelah pola selesai kemudian akan dilanjutkan dengan membuat rancangan bahan dan harga. Tujuan dari pembuatan rancangan bahan dan harga ini, agar peneliti mengetahui berapa bahan yang diperlukan dan berapa jumlah harga dari bahan yang akan digunakan untuk pembuatan busana pesta malam.

Tahap Pelaksanaan

Setelah tahap persiapan selesai, kemudian dilanjutkan dengan pelaksanaan. Pada tahap pelaksanaan meliputi meletakkan pola diatas bahan yang disesuaikan dengan arah serat dan motif kain, kemudian dilanjutkan dengan memotong kain/bahan sesuai dengan pola, setelah itu dilanjutkan dengan proses penjelujuran dan penyambungan bagian-bagian dari busana pesta. Setelah proses penjelujuran selesai, dilanjutkan dengan evaluasi I. Pada proses ini, busana dipakai oleh seorang model dan dicek apakah busana tersebut sudah pas dan sesuai dengan bentuk desain busana yang akan dikembangkan. Kemudian dilanjutkan dengan proses menjahit secara permanen bagian-bagin dari busana pesta. Setelah selesai proses menjahit, selanjutnya dilakukan evaluasi II, tujuan dari evaluasi ini adalah untuk 
mengecek kembali hasil jahitan setelah dilakukan proses menjahit dan juga melakukan proses finishing pada busana pesta.

\section{Implementasi (implementation)}

Setelah melakukan tahap development dan pengembangan busana pesta malam dengan sumber ide busana Ratu Elizabeth Kerajaan Inggris, kemudian dilakukan tahap implementation melalui uji uji ahli produk.Untuk uji produk peneliti melibatkan 2 orang ahli produk.

Pada tahap uji produk peneliti melakukan uji produk yang telah dikembangkan berupa busana pesta malam. Adapun subyek uji produk yaitu 2 orang ahli busana, diantaranya lbu Putu Ria Yunita selaku owner dari Ria Butik dan Luh Nusari, S.Pd. selaku staf pengajar di SMK Negeri 2 Singaraja.

Data yang diperoleh dari hasil uji produk yang terdiri dari 2 orang uji ahli, selanjutnya dianalisis menggunakan rumus Tegeh dkk (2014) sebagai berikut:

$$
\begin{aligned}
& \text { Presentase ahli } 1=\frac{81}{95} \times 100 \%=85,26 \% \\
& \text { Presentase ahli } 2=\frac{91}{95} \times 100 \%=95,78 \% \\
& \text { Rerata presentase }=\frac{181,04}{2}=90,52 \%
\end{aligned}
$$

Sehingga dapat disimpulkan bahwa dari pengembangan busana pesta malam dengan sumber ide busana Ratu Elizabeth Kerajaan Inggris memiliki kualifikasi sangat baik dengan tingkat pencapaian $90,52 \%$.

\section{Evaluasi (evaluation)}

Setiap tahap yang dilakukan oleh peneliti tidak terlepas dari kesalahan sehingga setiap tahap dapat dilakukan evaluasi.Evaluasi yang dilakukan adalah evaluasi secara formatif. Tujuan dari evaluasi ini adalah memperbaiki busana pesta malam yang telah dikembangkan.Evaluasi dilakukan untuk perbaikan-perbaikan sesuai dengan penilaian dan masukan yang diberikan oleh ahli busana.Pada tahapan ini peneliti melakukan evaluasi menurut hasil penilaian dari ahli busana dan memperbaiki busana pesta malam sesuai dengan masukan dan saran yang diberikan oleh ahli busana.

\section{Hasil Pengembangan Busana Pesta Malam dengan Sumber Ide Busana Ratu Elizabeth Kerajaan Inggris.}

Hasil dari pengembangan busana pesta malam dengan sumber ide busana Ratu Elizabeth Kerajaan Inggris merupakan busana yang dibuat dengan mengambil sumber ide busana Ratu Elizabeth Kerjaan Inggris.Selain mengambil sumber ide busana Ratu Elizabeth, sumber ide lainnya yaitu warnawarna yang digemari Ratu Elizabeth dan aksesoris dan milineris yang digunakan oleh Ratu Elizabeth.

Bentuk dari busana pesta terinspirasi dari bentuk busana pesta Ratu Elizabeth, dimana bentuk busana tersebut menyempit pada bagian atas mengikuti bentuk tubuh pemakai dan melebar pada bagian bawah. Sedangkan untuk pemilihan warna, busana pesta menggunakan warna biru dan silver. Warna biru dan silver terinspirasi dari karakteristik warna busana yang sering digunakan Ratu Elizabeth, dimana Ratu Elizabeth gemar menggunakan warnawarna busana yang cerah seperti merah, kuning, biru,hijau, dan orange.

Untuk aksesoris dan milineris, peneliti terinspirasi dari bentuk aksesoris dan milineris yang sering digunakan oleh Ratu Elizabeth.Salah satunya yaitu topi.Ratu Elizabeth sangat gemar menggunakan topi untuk kegiatan kerajaan. Dari bentuk topi tersebut penulis memodifikasi menjadi sebuah aksesoris kepala yang berbentuk mirip seperti topi dengan menggunakan warna yang sama seperti warna busana, yaitu warna biru dan silver. Untuk jenis bahan yang digunakan yaitu, kain satin berwarna silver sebagai bahan utama yang dipadukan dengan kain brokat berwarna biru. Untuk model busana pertama menggunakan kain tile kulit pada bagian atas sebagai bahan utama yang diaplikasikan kain brokat berwarna biru. Sedang untuk busana yang ke-2 menggunakan aplikasi hiasan kain kaca berwarna silver pada 
bagian sisi kanan dan kiri. Untuk bahan furing menggunakan kain hero berwarna silver. Bahan pendukung lainnya dari pembuatan busana ini antara lain kain tile kaku sebagai bahan pengembangan pada bagian rok. Selain itu terdapat juga kain PEMBAHASAN

1. Proses Pengembangan Busana Pesta Malam dengan Sumber Ide Busana Ratu Elizabeth Kerajaan Inggris.

Dalam pengembangan busana pesta malam dengan sumber ide busana Ratu Elizabeth Kerajaan Inggris ini peneliti menggunakan penelitian pengembangan model ADDIE (analysis, design, development, implementation, evaluation). Pada tahap analysis (analisis) peneliti melakukan analisis terhadap model busana sering yang sering digunakan oleh Ratu Elizabeth. Selain menganalisis model busana peneliti juga menganalisis dari warna dan karakteristik busana Ratu Elizabeth. Tujuan menganalisis dari karakteristik dan model busana dari Ratu Elizabeth adalah untuk memperoleh informasi mengenai model busana yang akan dikembangkan.

Setelah melakukan analisis, tahap selanjutnya adalah design (desain). Tahap kedua yang peneliti lakukan adalah mendesain model busana pesta malam yang akan dikembangkan. Setelah melakukan analisis diharapkan dapat menciptakan sebuah desain busana pesta malam sesuai dengan karakteristik busana pesta Ratu Eliezabeth Kerajaan Inggris.

Berdasarkan desain yang telah dibuat, peneliti melangkah ke tahap development (pengembangan). Pada tahap ini peneliti melakukan langkahlangkah pengembangan yang terdiri 3 tahapan yaitu, persiapan, pelaksanaan, evaluasi.Pada tahap persiapan terdiri dari pengambilan ukuran untuk pembuatan busana pesta malam, pembuatan pola dan merancang bahan dan harga. Tahap pelaksanaan terdiri dari memotong bahan gula sebagai bahan penegak didalam pembuatan longtorso.Dari sumber ide tersebut terciptalah sebuah busana pesta malam dengan sumber ide busana Ratu Elizabeth Kerajaan Inggris.

sampai dengan proses menjahit. Ditahap evaluasi, mengecek keseluruhan dari bagian-bagian busana dari busana sampai dengan aksesoris.

Setelah melakukan pengembangan selanjutnya yaitu tahap implementasi (implementation).Pada tahap ini produk yang dikembangkan dilakukan uji coba kepada para ahli.Untuk pengambilan data uji coba, menggunakan lembar kuisioner. Subyek uji coba dari penelitian ini adalah 2 orang ahli busana, yaitu Putu Ria Yunita pemilik dari Ria Butik dan Luh Nusari S.Pd dari guru SMK Negeri 2 Singaraja.

Langkah selanjutnya yaitu evaluasi. Pada tahap ini, penulis melakukan evaluasi terhadap hasil uji produk dari ahli busana. Hasil evaluasi akan dijadikan sebagai acuan dalam mengembangkan produk yang sejenis. Adapun kekurangan dari produk yang penulis kembangkan yaitu: detail desain busana kurang rapi, penggunaan kain kuffner untuk mendukung dalam pembuatan bustier, teknik jahit disesuaikan dengan karakteristik busana pesta. Dari kekurangan hasil jadi produk busana, akan dijadikan refrensi untuk mengembangkan produk busana yang serupa.

2. Hasil Pengembangan Busana Pesta Malam delizabetngan Sumber Ide Busana Ratu Elizabeth Kerajaan Inggris.

Dari hasil penelitian yang telah penulis paparkan, busana pesta yang dikembangkan memiliki kualifikasi sangat baik berdasarkan hasil uji ahli busana. Adapun hasil dari analisis data menggunakan analisis deskritif kualitatif adalah sebagai berikut: 


\begin{tabular}{lll}
\hline Ahli isi & Ahli produk \\
Dari hasil uji isi untuk kuisioner & Hasil produk memiliki kualifikasi \\
pengembangan busana malam dengan sumber & sangat baik dengan tingkat \\
ide busana Ratu Elizabeth Kerajaan Inggris & pencapaian 90,52\%. \\
terdapat 6 indikator yang terdiri dari 19 butir. & \\
Terdapat 17 butir valid dan 2 butir tidak valid. & \\
Perbaiki kata-kata yang masih sedikit rancu. & $\begin{array}{l}\text { Pergunakan kuffner pada } \\
\text { pembuatan longtorso. }\end{array}$ \\
& $\begin{array}{l}\text { Untuk gaun 2 pcs,bagian top } \\
\text { harap dipanjangkan } \pm 8 \text { cm untuk } \\
\text { menutup kemungkinan jeda pada }\end{array}$ \\
& saat model berjalan.
\end{tabular}

Pengembangan produk berupa busana pesta malam dengan sumber ide busana Ratu Elizabeth menciptakan sebuah produk dengan kreasi yang baru.. Hal ini sesuai dengan pengertian pengembangan sumber ide dalam penelitian Bella Yosuanti Magdalena dengan judul Busana Pesta Malam dengan Sumber Ide Kesenian Bambu Gila yang menyebutkan bahwa "Sumber ide merupakan sesuatu hal yang dapat menimbulkan rangsangan akan lahirnya suatu kreasi" (Widjiningsih, 2006;70).

Dalam pengembangan busana pesta malam dengan sumber ide busana Ratu Elizabeth Kerajaan Inggris mengambil bentuk dasar dari busana pesta yang sering digunakan Ratu Elizabeth yaitu menyempit pada bagian atas dan melebar pada bagian bawah.Untuk warna busana disesuaikan dengan karakteristik busana yang digemari Ratu Elizabeth yaitu busana dengan warna-warna cerah.Pada pemilihan bahan menggunakan bahan satin yang dikombinasikan dengan kain brokat.Busana pesta yang dikembangkan masih tetap mempertahankan bentuk dan ciri khas dari busana Ratu Elizabeth. Berikut merupakan hasil pengembangan busana pesta malam dengan sumber ide Busana Ratu Elizabeth Kerajaan Inggris.

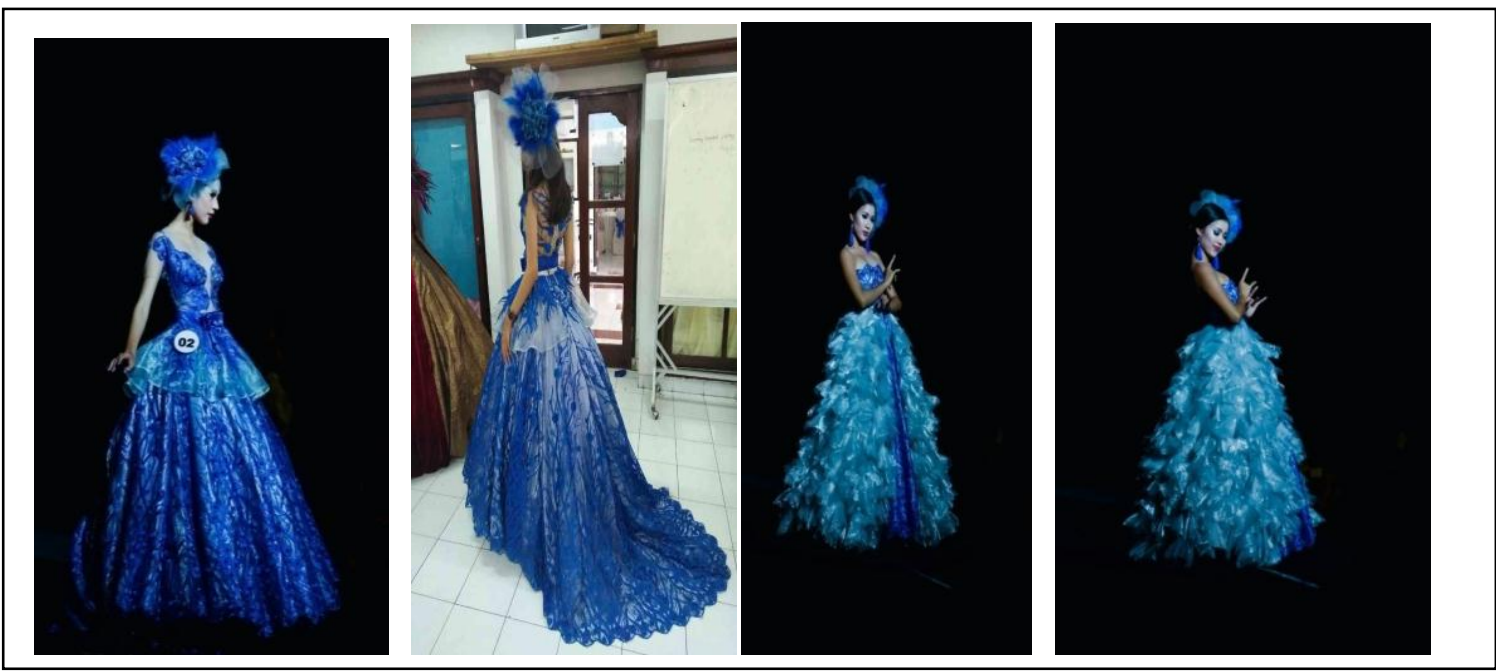


Gambar 3. Hasil Jadi Pengembangan Busana Pesta Malam

\section{SIMPULAN DAN SARAN Rangkuman}

Busana merupakan kebutuhan pokok yang harus dipenuhi oleh setiap orang (Siskawati:2010:1). Pentingnya busana dalam kehidupan sehari-hari membuat model busana semakin berkembang. Perkembangan busana terjadi disetiap belahan dunia, Salah satunya di Negara Inggris. Pada umumnya pakain khas di Negara Inggris sering kita lihat didalam sebuah cerita dongeng yng sering digunakan oleh seorang putri, karena Inggris merupakan sebuah negara kerajaan. Bentuk busana ini menyempit pada bagian atas seperti korset dan melebar pada bagian bawah.Pada saat ini Negara Inggris dipimpin oleh seorang Ratu, yang bernama Ratu Elizabeth.Ratu Elizabeth sangat dihormati oleh rakyatnya.Seringkali busana yang dipakai Ratu Elizabeth menjadi sorotan bagi masyarakat luas khususnya masyarakat Inggris. Ratu Elizabeth adalah seorang Ratu yang gemar menggunakan busana dengan warna-warna yang cerah. Hal ini dilakukan agar Ratu Elizabeth mudah dikenali oleh publik.Selain itu busana yang digunakan Ratu Elizabeth memakai hiasan berupa manik-manik dan bordiran.

Dengan adanya hal tersebut, penulis mengembangkan busana pesta malam dengan sumber ide busana Ratu Elizabeth Kerajaan Inggris. Adapun tujuan dari penelitian ini adalah: 1) untuk mengetahui proses pengembangan busana pesta malam dengan sumber ide Busana Ratu Elizabeth Kerajaan Inggris, 2) untuk memaparkan hasil pengembangan busana pesta malam dengan sumber ide busana Ratu Elizabeth Kerajaan Inggris.

Metode penelitian yang digunakan yaitu penelitian pengembangan (Research and Development). Model penelitian pengembangan yang digunakan yaitu penelitian pengembangan model ADDIE. Model penelitian ini terdiri dari lima langkah yaitu, analisis (analyze), perancangan (design), pengembangan (development), evaluasi (evaluation).

Metode pengumpulan data ini dengan menggunakan kuisioner kepada subyek penelitian yaitu 2 orang ahli isi dan 2 orang ahli busana. Data tersebut kemudian dianalisis menggunakan rumus dari Tegeh dkk (2014) sebagai berikut:

$N=\frac{\text { skorperolehan }}{\text { Skormaksimal }} \times 100 \%$

Untuk melihat tingkat pencapaian pengembangan busana pesta malam dengan sumber ide busana Ratu Elizabeth Kerajaan Inggris berdasarkan perhitungan data deskriptif maka ditetapkan kriteria sesuai tabel tingkat pencapaian pada tabel 3.4.Berdasarkan pengolahan dan analisis data yang telah peneliti lakukan, didapatkan hasil penelitian yaitu pengembangan busana pesta malam dengan sumber ide busana pesta malam dengan sumber ide busana Ratu Elizabeth Kerajaan Inggris memiliki kualifikasi sangat baik.

\section{Simpulan}

1. Proses Pengembangan Busana Pesta Malam dengan Sumber Ide Busana Ratu Elizabeth Kerajaan Inggris.

Proses pengembangan busana pesta malam dengan sumber ide busana Ratu Elizabeth Kerajaan Inggris menggunakan langkah-langkah pengembangan model ADDIE. Dimana langkah-langkah tersebut terdiri dari lima langkah yaitu: anlisis (analyze), perancangan (design), pengembangan (development), implementasi (implementation), evaluasi (evaluation).

Pada proses analisis peneliti melakukan analisis terhadap sumber ide yang dikembangkan menjadi busana pesta malam. Kemudian dilanjutkan dengan proses perancangan atau desain. Pada proses ini peneliti membuat desain busana pesta malam berdasarkan dari analisis sumber ide. Setelah melakukan proses perancangan, kemudian tahap 
selanjutnya yaitu pengembangan. Pada proses pengembangan terdiri dari tiga langkah yaitu, persiapan, pelaksanaan, dan evaluasi. Tahap selanjutnya yaitu implementasi, pada tahap implementasi dilakukan uji produk terhadap hasil dari pengembangan busana. Subyek uji produk merupakan 2 orang ahli busana, yaitu: Putu Ria Yunita merupakan pemilik dari Ria Butik dan Luh Nusari, S.Pd dari SMK Negeri 2 Singaraja. Tahap terakhir yaitu evaluasi, pada tahap ini penulis melakukan evaluasi terhadap hasil dari uji produk berupa busana pesta malam. Hasil evaluasi dipakai acuan dan refrensi untuk mengembangkan keterampilan khususnya dibidang busana.

2. Hasil Pengembangan Busana Pesta Malam dengan Sumber Ide Busana Ratu Elizabeth Kerajaan Inggris.

Berdasarkan hasil pengembangan busana yang penulis lakukan, didapatkan hasil pengembangan busana pesta malam dengan sumber ide Busana Ratu Elizabeth Kerajaan Inggris memiliki kualifikasi sangat baik dengan presentase peroleh 90,52\% berdasarkan hasil penilaian ahli busana. Dari hasil penilaian tersebut menunjukkan bahwa produk yang dikembangkan masih belum sempurna dan perlu adanya perbaikan-perbaikan dari hasil pengembangan busana pesta malam dengan sumber ide busana Ratu Elizabeth Kerajaan Inggris.

\section{Saran}

Berdasarkan hasil yang diperoleh dari penelitian ini bahwa pengembangan busana pesta malam dengan sumber ide busana Ratu Elizabeth Kerajaan Inggris ini mendapatkan penilaian dengan kualifikasi sangat baik dari penilaian ahli busana. Sehingga bisa dijadikan sebagai acuan bagi pengembangan busana pesta malam selanjutnya dengan mengambil sumber ide yang sama.

\section{DAFTAR RUJUKAN}

Bryka. 2012. Perkembangan Mode Busana. Jakarta: Rineka Cipta.
Siskawati. 2010. Perkembangan Model Busana. Jakarta: Rineka Cipta.

Tegeh, I Made dkk.2014. Model Penelitian Pengembangan. Singaraja: Graha IImu.

Widjiningsih. 2006. Konstruksi Pola Busana. Yogyakarta: IKIP Yogyakarta. 